\title{
Significance of endotoxin in lethal synergy between bacteria associated with sudden infant death syndrome: follow up study
}

\author{
N M Sayers, D B Drucker, J A Morris, D R Telford
}

\begin{abstract}
Aim-To investigate the role of endotoxin in synergy between bacterial toxins associated with sudden infant death syndrome (SIDS).

Methods-Extracellular toxins of 13 isolates of Staphylococcus from SIDS victims and matched healthy infants were tested for lethal toxicity in chick embryos with and without standard endotoxin (used at 1.00 ng/embryo). Endotoxin and toxins from staphylococci were used at dilutions with negligible lethality.

Results-Simultaneous injection of nonlethal levels of endotoxin and toxins from 11 of the 13 staphylococcal isolates tested produced lethal toxicity that was 111 to $613 \%$ greater than expected by an additive effect alone. This was highly significant and occurred even in the absence of staphylococcal enterotoxins or toxic shock syndrome toxin-1.

Conclusion-Endotoxin enhancement of staphylococcal toxin lethality could be partly responsible for the clinical outcome in SIDS.
\end{abstract}

( $f$ Clin Pathol 1996;49:365-368)

Keywords: lethal synergy, sudden infant death syndrome, endotoxin, bacteria.

Sudden infant death syndrome (SIDS) is the main cause of post-perinatal infant mortality in the UK. ${ }^{1}$ The syndrome is significantly associated with a number of feature ${ }^{23}$ : SIDS is uncommon in the first month of life and rare after the first year of life; the number of deaths peaks at two to three months of age, during the winter months and between 2400 and 0600 hours. In addition, there is persuasive evidence that viral infections of the upper respiratory tract predispose to SIDS. ${ }^{45}$

The "common bacterial toxin hypothesis" is the only hypothesis that explains the characteristic age distribution of SIDS. ${ }^{6}$ The hypothesis states that a viral infection of the upper respiratory tract can lead to a "supra-infection" by commensal bacteria, and if this occurs at the same time as infantile immunoglobulins are at their lowest (at approximately two to three months of age) the baby is at risk of SIDS.
Studies have shown that SIDS victims, compared with matched healthy controls: (1) have a higher carriage rate of staphylococci and coliforms in their nasopharynx $x^{7}$; and (2) are significantly more likely to harbour a toxigenic strain in their nasopharynx. ${ }^{8}$ It has also been shown that toxins from staphylococci and enterobacteria interact synergistically to produce a lethal effect following injection into chick embryos. ${ }^{9}$

The aim of this study is to explore the role of endotoxin in SIDS by investigating the interaction between endotoxin and extracellular toxin preparations of staphylococci using a chick embryo bioassay. Endotoxin or lipopolysaccharide is the primary component of Gram negative bacteria responsible for the pathophysiological response to septic shock. ${ }^{10}$

\section{Methods}

The staphylococcal strains used in this study were isolated from pernasal swabs (PNS) taken from SIDS victims at the earliest opportunity and from age and season matched healthy babies. The collection of samples has been described fully elsewhere. ${ }^{7-9}$

\section{BACTERIA TESTED}

Thirteen staphylococcal isolates were tested and details are presented in table 1 . Bacterial identification was confirmed using commercially available API STAPH kits (BioMèrieux (UK) Ltd, Basingstoke, UK) which

Table 1 Staphylococcus species type, code and concentration of toxin preparations used in study

\begin{tabular}{lclll}
\hline $\begin{array}{l}\text { Staphylococcal } \\
\text { species }\end{array}$ & $\begin{array}{l}\text { Study } \\
\text { Number }\end{array}$ & $\begin{array}{l}\text { Dilution } \\
\text { used }\end{array}$ & $\begin{array}{l}\text { Percentage } \\
\text { lethality }\end{array}$ & $\begin{array}{l}\text { Toxins } \\
\text { produced }\end{array}$ \\
\hline$S$ aureus & $1^{*}$ & $1 / 1$ & 18 & $\mathrm{C}$ \\
$S$ aureus & $2^{*}$ & $1 / 1$ & 23 & $\mathrm{C}$ \\
$S$ aureus & $3^{*}$ & $1 / 1$ & 0 & $\mathrm{C}$ \\
$S$ aureus & $4^{*}$ & $1 / 1$ & 0 & - \\
$S$ aureus & $5^{*}$ & $1 / 1$ & 9 & - \\
$S$ aureus & $6^{*}$ & $1 / 2$ & 0 & $\mathrm{C}$ \\
$S$ aureus & $7^{*}$ & $1 / 8$ & 9 & TSST-1 \\
$S$ aureus & $8 \dagger$ & $1 / 4$ & 9 & $\mathrm{D}$ \\
$S$ aureus & $9 \dagger$ & $1 / 1$ & 23 & - \\
$S$ aureus & $10 \dagger$ & $1 / 1$ & 15 & - \\
$S$ aureus & $11 \dagger$ & $1 / 16$ & 0 & TSST-1 \\
$S$ aureus & $12 \dagger$ & $1 / 1$ & 0 & C, D \\
S epidermidis & $13 \dagger$ & $1 / 16$ & 9 & - \\
\hline
\end{tabular}

* Bacteria isolated from infants who died of SIDS; † bacteria isolated from healthy controls; $\mathrm{C}=$ staphylococcal enterotoxin $\mathrm{C}$; $\mathrm{D}=$ enterotoxin D; TSST -1 = toxic shock syndrome toxin- 1 .
Correspondence to: Dr D B Drucker, S University of Manchester, Turner Dental School,

Accepted for publication 12 December 1995

School of Biological
Sciences,
University of
Manchester,
Manchester
N M Sayers
D B Drucker
Department of
Pathology, Royal
Lancaster Infirmary,
Lancaster
J A Morris
D R Telford
Correspondence to:
Dr D B Drucker, School of
Biological Sciences,
University of Manchester,
Turner Dental School,
Manchester M15 6FH.
Accepted for publication
12 December 1995


were used strictly in accordance with the manufacturer's instructions. All isolates were preserved at $-20^{\circ} \mathrm{C}$.

Two staphylococcal species were tested, Staphylococcus aureus and Staphylococcus epidermidis. Isolates 1-7 were isolated from the PNS of SIDS victims whereas isolates 8-13 were isolated from the PNS of normal healthy infants (table 1). The Staphylococcus isolates were tested for the production of enterotoxins A to D (SEA-SED) and toxic shock syndrome toxin-1 (TSST-1) (table 1) by Antonnette Wieneke (Central Public Health Laboratory, Colindale, London, UK) using the SET-RPLA kit (TD900, Unipath, Basingstoke, UK). The manufacturer's instructions were followed except that the dilutions of the culture filtrates used were 1 in 2,1 in 10 and 1 in $100 .{ }^{11}$

\section{TESTING OF TOXICITY}

The bacterial isolates chosen were screened for lethal toxicity ${ }^{12}$ using a chick embryo assay system originally described by Eichhorn, ${ }^{13}$ which has the advantage of sensitivity to a very wide range of toxins.

The growth, harvesting and assessment of concentration of bacterial suspensions were carried out following previously published methods. ${ }^{912}$ Briefly, bacteria were grown on dialysis membranes overlain onto a plate of defined media ${ }^{14}$ and incubated at $37^{\circ} \mathrm{C}$ for 18 hours. Bacteria and supra-membranous cell products were collected by washing with Hanks' balanced salt solution (HBSS) (Sigma, Poole, Dorset, UK) and the concentration of each bacterial suspension in HBSS was assessed using a double-beam spectrophotometer (PyeUnicam, Cambridge, UK) set at $\lambda_{585 \mathrm{~nm}}$. Bacterial suspensions were compared by adjusting the suspensions to a standardised and notional absorbance (where $A=5 \cdot 0$ ), representing the undiluted sample. Bacteria were removed by centrifugation at $3000 \times g$ for 20 minutes, then filter sterilisation using a $0.2 \mu \mathrm{m}$ pore membrane filter (Gelman Sciences, Michigan, USA). The concentration of each crude toxin preparation was considered to be the same as that of the original bacterial suspension from which it was derived. Toxin preparations were stored at $-20^{\circ} \mathrm{C}$ and diluted as required with HBSS.

The biological activity of each crude toxin preparation was assessed by intravenous injection into 11-day old chick embryos. ${ }^{913}$ Briefly, $50 \mu \mathrm{l}$ of each toxin preparation (at the desired concentration) was injected into the chorio-allantoic vein of each embryo. If injection resulted in haemorrhage, the embryo was replaced. The survival of each embryo post-injection was assessed after an 18 hours incubation period.

\section{PRE-SYNERGY TOXICITY TESTING}

Putative toxins from staphylococci were tested undiluted, and diluted ( 1 in 2,1 in 4,1 in 8 , 1 in 16 , and 1 in 32) with HBSS. Two separate toxin preparations from each individual bac-
Table 2 Percentage lethality of standard endotoxin assessed over a range of concentrations in the chick embryo assay (see text for details)

\begin{tabular}{cc}
\hline $\begin{array}{l}\text { Concentration of endotoxin injected } \\
\text { into each egg (pg/embryo) }\end{array}$ & Percentage lethality \\
\hline 0 & 1 \\
250 & 0 \\
500 & $11 \cdot 5$ \\
$1000^{*}$ & $11 \cdot 5$ \\
2000 & 34.6 \\
3000 & $53 \cdot 8$ \\
4000 & 53.3
\end{tabular}

* Concentration used in synergy experiment.

terial isolate were tested in a minimum of 11 eggs. Endotoxin derived from Escherichia coli 055:B5 (Sigma) was tested at 5, 10, 20, 40, 80 , and $160 \mathrm{ng} / \mathrm{ml}$. When injected $(50 \mu \mathrm{l})$ into each individual egg, this equates with a final concentration of $250 \mathrm{pg}, 500 \mathrm{pg}$ and 1, 2, 4, and 8 ng per embryo. Embryos were also challenged with $50 \mu \mathrm{l}$ of HBSS alone (negative controls).

For both staphylococcal toxins (table 1) and endotoxin (table 2), the dilution factor was noted at which lethal toxicity in the chick embryo was less than, or equal to, $25 \%$ of eggs challenged.

\section{SYNERGY EXPERIMENTS}

Staphylococcal toxins and endotoxin were combined at non-lethal concentrations (determined in the pre-synergy experiments) and then diluted 1 in 2,1 in 4,1 in 8,1 in 16 , and 1 in 32 with HBSS. When toxins from staphylococci were combined with endotoxin, the concentration of both was initially used at twice that indicated in tables 1 and 2 ; on mixing, this resulted in each toxin being diluted by 1 in 2 , thereby arriving at the required concentration. A minimum of 11 chick embryos was used to test each combination.

\section{Results}

Analysis of enterotoxin production by the staphylococcal isolates showed (table 1) that isolates $1-3,6$, and 12 produced staphylococcal enterotoxin C (SEC), isolates 8 and 12 produced staphylococcal enterotoxin D (SED), isolates 7 and 11 produced TSST-1, and isolates $4,5,9,10$, and 13 produced neither detectable enterotoxin nor TSST-1. Staphylococcal strains isolated from SIDS victims predominantly produced SEC (four of seven isolates) compared with matched healthy controls (one of six isolates).

The pre-synergy experiments indicated that the lethality of each staphylococcal toxin preparation varied greatly, and that the concentrations of toxin preparations used in the subsequent synergy experiments ranged from undiluted to a dilution factor 1 in 8 of that of the original concentration (table 1).

Endotoxin was used at a concentration of $1 \mathrm{ng} / \mathrm{embryo}(20 \mathrm{ng} / \mathrm{ml})$ which killed $11.5 \%$ of the embryos challenged (table 2).

The expected effect of combining sub-lethal doses of staphylococcal toxins with endotoxin was originally estimated by a simple addition 
Table 3 Comparison of actual and expected (by addition) lethality of toxin preparations from staphylococci in presence of endotoxin

\begin{tabular}{|c|c|c|c|c|}
\hline \multicolumn{2}{|c|}{$\begin{array}{l}\text { Staphylococcal } \\
\text { species and code }\end{array}$} & $\begin{array}{l}\text { Percentage lethality } \\
\text { without endotoxin }\end{array}$ & $\begin{array}{l}\text { Percentage lethality } \\
\text { with endotoxin }\end{array}$ & $\begin{array}{l}\text { Expected percentage } \\
\text { lethality with endotoxin }\end{array}$ \\
\hline$S$ aureus & $1^{*}$ & 18 & 91 & $29 \cdot 5$ \\
\hline$S$ aureus & $2 *$ & 23 & 46 & $34 \cdot 5$ \\
\hline$S$ aureus & $3^{*}$ & 0 & 73 & $11 \cdot 5$ \\
\hline$S$ aureus & $4^{*}$ & 0 & 36 & 11.5 \\
\hline$S$ aureus & $5^{*}$ & 9 & 55 & $20 \cdot 5$ \\
\hline$S$ aureus & $6^{*}$ & 0 & 64 & 11.5 \\
\hline$S$ aureus & $7^{*}$ & 9 & 55 & 20.5 \\
\hline$S$ aureus & $8+$ & 9 & 55 & $20 \cdot 5$ \\
\hline$S$ aureus & $9+$ & 23 & 73 & $34 \cdot 5$ \\
\hline$S$ aureus & $10 f$ & 15 & 82 & $26 \cdot 5$ \\
\hline$S$ aureus & $11 \dagger$ & 0 & 82 & $11 \cdot 5$ \\
\hline$S$ aureus & $12 \dagger$ & 0 & 73 & $11 \cdot 5$ \\
\hline$S$ epidermidis & $13 \dagger$ & 9 & 27 & $20 \cdot 5$ \\
\hline
\end{tabular}

* Bacteria isolated from infants who died of SIDS; † bacteria isolated from healthy controls. Concentrations of endotoxin and staphylococcal toxins are given in tables 1 and 2 . Difference between observed and expected values is significant at $p=0.0001$ (Wilcoxon signed rank test).

Table 4 Lethal toxigenicity of staphylococcal toxins in the presence of endotoxin diluted with HBSS in the chick embryo assay

\begin{tabular}{|c|c|c|c|c|c|c|c|}
\hline \multirow{2}{*}{$\begin{array}{l}\text { Staphylococcal } \\
\text { species and code }\end{array}$} & & \multicolumn{6}{|c|}{$\begin{array}{l}\text { Percentage lethality of staphylococcal } \\
\text { toxins plus endotoxin diluted with } H B S S\end{array}$} \\
\hline & & $1 / 1$ & $1 / 2$ & $1 / 4$ & $1 / 8$ & $1 / 16$ & $1 / 32$ \\
\hline$S$ aureus & $1^{*}$ & 91 & 27 & 36 & 18 & 0 & 9 \\
\hline$S$ aureus & $2^{*}$ & 46 & 18 & 9 & 18 & 9 & 9 \\
\hline$S$ aureus & $3^{*}$ & 73 & 36 & 9 & 0 & 0 & 0 \\
\hline$S$ aureus & $4^{*}$ & 36 & 27 & 18 & 0 & 9 & 0 \\
\hline$S$ aureus & $5^{*}$ & 55 & 55 & 55 & 46 & 46 & 27 \\
\hline$S$ aureus & $6^{*}$ & 64 & 46 & 18 & 0 & 9 & 0 \\
\hline$S$ aureus & $7^{*}$ & 55 & 18 & 27 & 0 & 9 & 0 \\
\hline$S$ aureus & $8 \dagger$ & 55 & 18 & 27 & 18 & 0 & 0 \\
\hline$S$ aureus & $9 \dagger$ & 73 & 82 & 73 & 46 & 27 & 18 \\
\hline$S$ aureus & $10+$ & 82 & 64 & 64 & 36 & 36 & 27 \\
\hline$S$ aureus & $11 \dagger$ & 82 & 55 & 9 & 9 & 9 & 9 \\
\hline$S$ aureus & $12 \dagger$ & 73 & 73 & 55 & 55 & 55 & 55 \\
\hline$S$ epidermidis & $13 t$ & 27 & 18 & 9 & 0 & 0 & 0 \\
\hline
\end{tabular}

* Bacteria isolated from infants who died of SIDS; † bacteria isolated from healthy controls.

Concentrations of endotoxin and staphylococcal toxin preparations used are given in tables 1 and 2.

(table 3). This assumed that both the staphylococcal toxin and endotoxin would act separately (additively) as if tested alone in the chick assay. The results of the actual combinations are shown in tables 3 and 4 . When endotoxin and toxin preparations of staphylococcal isolate numbers 1 and 3-12 were combined a notable increase in lethality was seen ranging from 111 to $613 \%$ over and above that expected. Determination of statistical significance by the Wilcoxon signed rank test revealed that the enhancement of lethality was highly significant $(p=0.0001)$. This synergistic activity was dilutable by 1 in 2 to 1 in 32 , depending on the staphylococcal isolate (table 4). Toxin preparations from isolates 2 ( $S a u$ reus) and 13 ( $S$ epidermidis) showed less noticeable apparent synergy than others with endotoxin; the maximum rise in toxicity seen was 33 and $31 \%$, respectively. Isolate 2 had been cultured from the PNS of a SIDS victim (table 1), whereas isolate 13 had been cultured from the PNS of a healthy infant (table 1 ).

\section{Discussion}

The results presented herein show that Gram negative endotoxin and extracellular toxins from staphylococci act synergistically to produce a lethal effect in chick embryos. Eleven of the 13 staphylococcal isolates tested stim- ulated a lethal synergistic effect with endotoxin. Of those 11 isolates, four produced SEC, two produced SED, two produced TSST-1, and four did not produce any detectable enterotoxins or TSST-1. These results suggest that the presence of any particular enterotoxin or TSST-1 is not an absolute requirement for lethal synergy to occur between staphylococci and endotoxin. In addition, as table 4 illustrates, the presence of enterotoxin or TSST-1 (vide supra) does not guarantee high dilutability of combined lethality of staphylococcal toxin plus endotoxin. Staphylococci produce other extracellular toxins including exfoliating toxins (A and B), pyrogenic exotoxins (A, B and C), and leucocidin ${ }^{15}$ which may also be involved.

Toxins from two staphylococcal isolates (2 and 13) produced a less marked effect with endotoxin. Enterobacteria also produce a wide range of toxins other than endotoxin; these include haemolysins, vero-cell cytotoxin and proteases, ${ }^{1617}$ which could also act synergistically with staphylococci.

The physiological effects of endotoxin are varied. ${ }^{10}$ Gram positive toxins (including TSST-1, SEA, SEB and SEC $^{1819}$ ) can potentiate the activity of endogenous endotoxin by priming or activating macrophages. ${ }^{20}$ Endotoxin activity can also be potentiated by other antigens including influenza virus $\mathrm{A}^{2122}$; it has also been reported that SIDS victims are more likely to have depleted antibodies to endotoxin core than normal healthy controls. ${ }^{23}$ These observations are pertinent to the "common bacterial toxin hypothesis". 6

The experimental evidence described suggests that endotoxin produced by enterobacteria could play a role in the observed synergy between enterobacteria and staphylococci. ${ }^{9}$ Further work is in progress to identify additional staphylococcal toxins (other than enterotoxins and TSST-1) which may be involved in this process. As SIDS victims are more likely to harbour enterobacteria and staphylococci in their nasopharynx than normal healthy infants, ${ }^{7}$ this is of significance in the aetiology of SIDS. If bacterial toxins do have a pathogenetic role in SIDS then prevention based on immunisation is a possibility. ${ }^{2425}$

The authors wish to thank Antonnette Wieneke (Central Public Health Laboratory, Colindale, London, UK) for measuring staphylococcal enterotoxin and TSST-1 production.

We also wish to thank the Foundation for the Study of Infant Deaths (FSID) for their financial support.

1 Benetele $\mathrm{KH}$, Albani $\mathrm{M}$. Are there tests predictive for prolonged apnoea and SIDS? A review of epidemiological prolonged apnoea and SIDS? A review of epidemiological

2 Milner AD. Recent theories on the cause of cot death. BMF 1987;295:1366-8.

3 Li DK, Darling JR. Maternal smoking, low birth weight, and ethnicity in relation to sudden infant death syndrome. Ann $\mathcal{F}$ Epidemiol 1991;134:958-64.

4 Williams AL, Wren EC, Bretherton L. Respiratory viruses and sudden infant death. $B M \mathcal{F} 1984 ; 288: 1491-3$.

5 Jakeman KJ, Rushton DI, Smith H, Sweet C. Exacerbation of bacterial toxicity to infant ferrets by influenza virus: possible role in sudden infant death syndrome. $\mathcal{F}$ Infect Dis 1991;163:35-40.

6 Morris JA, Haran D, Smith A. Hypothesis: common bacterial toxins are a possible cause of sudden infant death syndrome. Med Hypth 1987;22:211-22.

7 Telford DR, Morris JA, Hughes P, Conway AR, Lee SM Barson AJ, Drucker DB. The nasopharyngeal bacteria Barson AJ, Drucker DB. The nasopharyngeal bacteria B18: $125-30$.

8 McKendrick N, Drucker DB, Morris JA, Telford DR, Bar- 
son AJ, Oppenheim BA. Bacterial toxins: a possible cause of cot death. f Clin Pathol 1992;45:49-53.

9 Sayers NM, Drucker DB, Morris JA, Telford DR. Lethal synergy between toxins of staphylococci and enterobacteria: implications for sudden infant death syndrome. f Clin Pathol 1995;48:929-32.

10 Martich DG, Boujoukos AJ, Suffredini AF. Response of man to endotoxin. Immunobiol 1993;187:403-16.

11 Wieneke AA. The detection of enterotoxin and toxic shock syndrome toxin-1 production by strains of Staphylococcus aureus with commercial RPLA kits. Int f Food Microbiol 1988;7:25-30.

12 Drucker DB, Aluyi HA, Morris JA, Telford DR, Gibbs A Lethal synergistic action of toxins of bacteria isolated from Lethal sy infat 799-801.

13 Eichhorn EA. A technique for the intravenous inoculation of chick embryos. Science 1940;92:245-6.

14 Guigard B. The amino acid requirements of microorganisms for growth. In: Sober HA, ed. Handbook of biochemistry. Cleveland, Ohio: Chemical Rubber Co., 1970:I-3-19.

15 Marrak P, Kappler J. The Staphylococcal enterotoxins and their relatives. Science 1990;248:705-11.

16 Holland IB, Kenny B, Blight M. Haemolysin secretion from E. coli. Biochimie 1990;72:131-41.

17 Bettelheim KA, Goldwater PN, Dwyer BW, Bourne AJ, Smith DL. Toxigenic Escherichia coli associated with sudden infant death syndrome. Scand f Infect Dis 1990; 22:467-76

18 Sugiyama H, McKissic EM, Bergdoll MS. Sensitivity of thorotrast-treated monkeys to staphylococcal enterotoxin. Proc Soc Exp Biol Med 1963;113:468-70.

19 Schlievert PM, Bettin KM, Watson DW. Purification and characterization of group A streptococcal pyrogenic exotoxin type C. Infect Immun 1977;16:673-9.

20 Beezhold DH, Best GK, Bonventre PF, Thompsom M Synergistic induction of interleukin-1 by endotoxin and toxic shock syndrome toxin-1 using rat macrophages. Infect Immun 1987;55:2865-9.

21 Husseini RH, Collie MH, Rushton DI, Sweet C, Smith $\mathrm{H}$. The role of naturally-acquired bacterial infection in influenza-related death in neonatal ferrets. Br f Exp Pathol 1983;64:559-69.

22 Collie MH, Rushton DI, Sweet C, Smith H. Studies of influenza virus infection in newborn ferrets. 7 Med Miinfluenza virus infection

23 Oppenheim BA, Barclay GR, Morris J, Knox F, Barson A Drucker DB, et al. Antibodies to endotoxin core in sudden infant death syndrome. Arch Dis Child 1994;70:95-8.

24 Corriveau CC, Danner RL. Antiendotoxin therapies for septic shock. Infect Agents Dis 1993;2:44-52.

25 Spapen HD, Diltoer M, Huyghens LP. Passive immunotherapy of gram-negative bacteraemia, sepsis and septic shock. Acta Clin Belg 1993;48:20-9. 